\title{
Efektivitas Penggunaan Media Permainan Ludo Kimia Berbasis Chemo-Edutainment (CET) Pada Materi Sistem Koloid Terhadap Hasil Belajar Siswa Kelas XI SMAN 3 Pariaman
}

\author{
L Indriliza ${ }^{1}$ and Iswendi ${ }^{1 *}$ \\ ${ }^{1}$ Pendidikan Kimia, Universitas Negeri Padang, Jl. Prof. Dr. Hamka Air Tawar Barat, \\ Padang Utara, Sumatera Barat 25171, Indonesia \\ *iswendi@fmipa.unp.ac.id
}

\begin{abstract}
This research is motivated by the lack of student participation in doing the exercises and the ineffectiveness of individual training because they are not competitive. This study aims to reveal the effectiveness of the use of chemo-edutainment-based ludo chemical (CET) games on the Colloid System material on the learning outcomes of class XI students of SMAN 3 Pariaman. The type of research used was a quasi-experimental design with a non-equivalent control group design. The population in this study were students of class XI MIPA SMAN 3 Pariaman. The research sample was taken using a purposive sampling technique so that the XI MIPA 1 class was selected as the experimental class and XI MIPA 2 class as the control class. Research data includes learning outcomes from the cognitive domain. The research instrument is a test of learning outcomes in the form of multiple choice questions that have been tested. The data analysis technique used was the two average similarity test (t-test) to determine the differences in learning outcomes and the N-Gain test to determine the increase in student understanding. The results showed an increase in understanding of learning outcomes that were better in the experimental class than in the control class. This is evidenced by the average posttest value of the experimental and control classes of 84.33 and 78.78 respectively and supported by hypothesis testing carried out by the $t$-test, namely count (2.607) $>t 1-\alpha(1.67)$ at the level of reality $\alpha=0.05$ with $\mathrm{dk}=70$ and opportunities $\mathrm{t} 0.95$. This is also evidenced by the average experimental class $\mathrm{N}$-Gain test of 0.77 with a high category and a control class of 0.67 with a moderate category. Thus it can be concluded that the use of media is an effective game of ludo chemical chemoedutainment (CET) with a high category in improving the learning outcomes of class XI students of SMAN 3 Pariaman..
\end{abstract}

\section{Pendahuluan}

Sistem Koloid merupakan salah satu materi pokok dalam mata pelajaran kimia yang dipelajari pada kelas XI SMA Semester II[1]. Materi sistem koloid memuat pengetahuan faktual, konseptual, dan prosedural. Pengetahuan faktual yang terdapat pada materi sistem koloid, misalnya: agar-agar, susu, cat, santan. Pengetahuan konseptual pada materi ini, misalnya: pengertian sistem koloid dan sifat-sifat koloid. Pengetahuan prosedural pada materi ini, misalnya: proses pembuatan koloid. Dari karakteristik materi tersebut, untuk memahami materi koloid secara utuh maka diperlukan suatu usaha seperti, banyak membaca, diskusi, dan mengerjakan latihan agar tercapai Indikator Pencapaian Kompetensi sesuai dengan Kurikulum 2013 Revisi. Untuk meningkatkan penguasaan pengetahuan siswa mengenai konsep, prinsip, dan prosedural yang telah dipelajari maka perlu dilakukan latihan[2].

Berdasarkan hasil wawancara yang telah dilakukan dengan guru kimia di SMAN 3 Pariaman, didapatkan informasi bahwa latihan yang diberikan guru masih berasal dari buku paket dan soal-soal yang dibuat sendiri oleh guru. Pengerjaan soal latihan pada umumnya dilakukan secara individu dan tidak 
berkompetitif. Hal ini tidak sesuai dengan karakteristik siswa yang suka berkelompok. Ada beberapa kekhususan tingkah laku sosial remaja, salah satunya adalah kesenangan berkelompok[3]. Berkompetisi sangat dibutuhkan dalam meraih suatu prestasi karena dengan berkompetisi akan ada dorongan individu melakukan suatu usaha untuk mencapai tujuan dengan cara bersaing untuk memperoleh hasil yang lebih baik dari orang lain[4]. Selanjutnya, diketahui juga bahwa siswa kurang berpartisipasi dalam mengerjakan soal-soal latihan. Hal ini memungkinkan hasil belajar yang diperoleh siswa tidak optimal. Oleh karena itu, diperlukan upaya untuk meningkatkan partisipasi dan motivasi siswa saat mengerjakan latihan sehingga dapat memantapkan konsep siswa agar hasil belajar siswa menjadi lebih baik. Salah satu upaya yang dapat digunakan adalah dengan menggunakan permainan sebagai media pembelajaran untuk latihan. Siswa pada usia 7-18 tahun masih cenderung menyukai permainan dalam proses pembelajaran[5].

Permainan sebagai media pembelajaran bertujuan untuk membantu siswa belajar secara berkelompok, meningkatkan kompetensi dan dapat menciptakan suasana belajar yang menyenangkan bagi siswa. Adanya permainan akan membuat siswa lebih berpartisipasi aktif dalam pembelajaran[6]. Media permainan edukatif, produktif, dan menyenangkan adalah semua alat permainan yang bersifat mendidik dan dapat digunakan dalam pembelajaran, menghasilkan nilai tinggi, dan menyenangkan ketika digunakan[7]. Salah satu media pembelajaran yang dapat digunakan pada materi sistem koloid adalah media pembelajaran berupa permainan yaitu Ludo Kimia berbasis Chemo-Edutaiment (CET).

Permainan ludo kimia berbasis CET adalah permainan ludo yang telah dimodifikasi dengan menggabungkan unsur chemo (kimia), education (pendidikan) dan entertainment (hiburan) sehingga menjadi sebuah media pembelajaran yang bersifat edukatif, menarik, dan menyenangkan untuk digunakan[8]. Media pembelajaran dalam bentuk permainan ludo ini mengajak siswa untuk bermain dalam kelompok sambil mengerjakan soal latihan materi sistem koloid. Dengan demikian akan dapat meningkatkan partisipasi dan motivasi siswa dalam belajar serta memantapkan konsep siswa terhadap pelajaran yang telah diberikan.

Permainan ludo sebagai media pembelajaran yang akan dipergunakan dalam penelitian ini disusun oleh Febriyeni (2019)[9]. Media ini telah di uji tingkat validitas dan praktikalitasnya, namun media ini belum di uji efektivitasnya terhadap hasil belajar siswa. Berdasarkan hasil analisis data diperoleh bahwa permainan ludo kimia berbasis CET sebagai media pembelajaran pada materi Sistem Koloid memiliki tingkat validitas dan praktikalitas yang sangat tinggi. Oleh karena itu, penulis melakukan penelitian dengan tujuan untuk mengungkapkan tingkat efektivitas penggunaan media permaianan ludo kimia berbasis CET pada materi Sistem Koloid terhadap hasil belajar siswa kelas XI SMAN 3 Pariaman.

\section{Metode}

Penelitian ini dilaksanakan pada bulan April 2019 dan bertempat di SMAN 3 Pariaman. Jenis penelitian yang digunakan pada penelitian ini adalah eksperimen semu (Quasi Experimental Design) dengan rancangan penelitian non-equivalent control group design. Bentuk rancangan penelitiannya dapat dilihat pada Tabel 1.

Tabel 1. Rancangan penelitian non-eqivalent control group design.

\begin{tabular}{c|c|c|c} 
Kelas & Pretest & Perlakuan & Posttest \\
\hline Eksperimen & $\mathrm{O}_{1}$ & $\mathrm{X}$ & $\mathrm{O}_{2}$ \\
\hline Kontrol & $\mathrm{O}_{3}$ & - & $\mathrm{O}_{4}$
\end{tabular}

Keterangan :

$\mathrm{O}_{1}$ dan $\mathrm{O}_{3}$ : pretest

$\mathrm{O}_{2}$ dan $\mathrm{O}_{4}$ : posttest

$\mathrm{X}^{2} \quad$ : Pembelajaran dengan menggunakan media permainan ludo kimia berbasis CET

Populasi dalam penelitian ini adalah seluruh siswa kelas XI MIPA di SMAN 3 Pariaman pada semester genap tahun ajaran 2018/2019. Sampel diambil dengan menggunakan teknik purposive sampling. Purposive sampling merupakan teknik pengambil sampel berdasarkan pertimbangan tertentu[10]. Kelas sampel terdiri dari dua kelas, yaitu XI MIPA 1 sebagai kelas eksperimen dan XI MIPA 2 sebagai kelas kontrol. Kelas eksperimen adalah kelas yang diberi perlakuan dengan menggunakan permainan ludo kimia berbasis CET sebagai media pembelajaran untuk latihan. Sedangkan kelas kontrol adalah kelas 
yang tidak diberi perlakuan dengan menggunakan media permainan ludo kimia berbasis CET sebagai media pembelajaran untuk latihan.

Variabel yang digunakan pada penelitian ini terdiri dari variabel bebas, variabel terikat, dan variabel kontrol.

a. Variabel independen/bebas, yaitu variabel yang mempengaruhi atau yang menjadi sebab perubahan/timbulnya variabel dependen yang disebut juga dengan variabel terikat[10]. Pada penelitian ini yang menjadi variabel bebas adalah pembelajaran dibantu media permainan ludo kimia berbasis CET pada kelas eksperimen dan pembelajaran tanpa menggunakan media permainan ludo kimia berbasis CET di kelas kontrol.

b. Variabel dependen/terikat, yaitu variabel yang dipengaruhi atau yang menjadi akibat, karena adanya variabel bebas[10]. Pada penelitian ini yang menjadi variabel terikat adalah hasil belajar siswa yang diperoleh dari hasil pretest dan posttest pada kelas eksperimen dan kelas kontrol.

c. Variabel kontrol, yaitu variabel yang dikendalikan atau dibuat konstan sehingga pengaruh variabel bebas terhadap variabel terikat tidak dipengaruhi oleh faktor luar yang tidak teliti[10]. Pada penelitian ini yang menjadi variabel kontrol semuanya haruslah dibuat sama diantaranya adalah model pembelajaran yang digunakan, materi, buku sumber, alokasi waktu, guru yang mengajar, cara mengajar, jenis dan jumlah soal yang diujikan adalah sama.

Data dalam penelitian ini adalah data primer yang diperoleh dari hasil belajar siswa pada kompetensi kognitif di kelas sampel melalui tes tertulis diawal (pretest) dan diakhir (posttest) pembelajaran. Sumber data adalah siswa kelas eksperimen dan kelas kontrol. Teknik analisis data yang digunakan dalam penelitian ini adalah uji N-Gain, Adapun tingkat kriteria N-Gain klasifikasi dapat dilihat pada Tabel 2.

Tabel 2. Kriteria N-Gain[11]

\begin{tabular}{c|c} 
N-Gain & Kriteria \\
\hline $\mathrm{g} \geq 0,7$ & Tinggi \\
\hline $0,7>\mathrm{g}>0,3$ & Sedang \\
\hline $\mathrm{g} \leq 0,3$ & Rendah
\end{tabular}

Uji N-Gain bertujuan untuk mengungkapkan efektivitas media yang digunakan dengan mengetahui peningkatan pemahaman siswa yang terjadi sebelum dan sesudah pembelajaran berdasarkan hasil pretest dan posttest pada kelas sampel. Uji normalitas bertujuan untuk melihat apakah sampel berasal dari populasi yang terdistribusi normal atau tidak. Uji homogenitas bertujuan untuk mengetahui apakah data pada kedua kelompok sampel sudah mempunyai varians yang homogen atau tidak. Uji-t digunakan untuk menguji hopotesis penelitian dengan mengetahui perbedaan hasil belajar dari kedua kelas sampel.

\section{Hasil dan Pembahasan}

\subsection{Hasil penelitian}

Data yang diperoleh dalam penelitian ini berupa hasil belajar siswa pada kompetensi kognitif. Penilaian hasil belajar dilakukan dengan memberikan tes awal (pretest) dan tes akhir (posttest) berupa soal objektif sebanyak 25 butir soal dengan 5 pilihan jawaban yang diambil dari 40 soal yang telah diujicobakan. Siswa yang menjawab benar diberi skor 1 dengan nilai 4 dan siswa yang menjawab salah diberi skor 0 dengan nilai 0 . Tes awal (pretest) diberikan sebelum memulai pembelajaran yang ditujukan untuk mengetahui kemampuan awal siswa. Secara ringkas hasil pretest siswa pada kelas sampel dapat dilihat pada Tabel 3 . 
Tabel 3. Distribusi Frekuensi Pretest Kelas Sampel

\begin{tabular}{|c|c|c|c|c|c|c|}
\hline \multirow{2}{*}{ No } & \multirow{2}{*}{$\begin{array}{c}\text { Skor } \\
\text { Pretest }\end{array}$} & \multirow{2}{*}{$\begin{array}{c}\text { Nilai } \\
\text { Pretest }\end{array}$} & \multicolumn{2}{|c|}{ Kelas Eksperimen } & \multicolumn{2}{|c|}{ Kelas Kontrol } \\
\hline & & & Frekuensi & Jumlah Nilai & Frekuensi & Jumlah Nilai \\
\hline 1 & 4 & 16 & - & - & 1 & 16 \\
\hline 2 & 5 & 20 & 3 & 60 & 2 & 40 \\
\hline 3 & 6 & 24 & 4 & 96 & 1 & 24 \\
\hline 4 & 7 & 28 & 3 & 84 & 4 & 112 \\
\hline 5 & 8 & 32 & 7 & 224 & 6 & 192 \\
\hline 6 & 9 & 36 & 6 & 216 & 4 & 144 \\
\hline 7 & 10 & 40 & 5 & 200 & 7 & 280 \\
\hline 8 & 11 & 44 & 2 & 88 & 3 & 132 \\
\hline 9 & 12 & 48 & 4 & 192 & 5 & 240 \\
\hline 10 & 13 & 52 & 2 & 104 & 1 & 52 \\
\hline 11 & 14 & 56 & - & - & 2 & 112 \\
\hline \multicolumn{3}{|c|}{ Jumlah } & 36 & 1264 & 36 & 1344 \\
\hline \multicolumn{3}{|c|}{ Rata-Rata } & & 35,11 & & 37,33 \\
\hline
\end{tabular}

Tabel 3 memperlihatkan bahwa nilai pretest terendah pada kelas eksperimen adalah 20 yang diperoleh oleh 3 orang siswa dan nilai tertinggi adalah 52 diperoleh oleh 2 orang siswa. Nilai pretest terendah pada kelas kontrol adalah 16 yang diperoleh oleh 1 orang siswa dan nilai tertinggi adalah 56 diperoleh oleh 2 orang siswa. Nilai rata-rata pretest kelas eksperimen adalah 35,11 dan nilai rata-rata pretest kelas kontrol adalah 37,33.

Tes akhir (posttest) diberikan setelah pertemuan terakhir pada proses pembelajaran yang bertujuan untuk mengetahui hasil belajar siswa setelah diberi perlakuan. Secara ringkas hasil posttest siswa pada kelas sampel dapat dilihat pada Tabel 4.

Tabel 4. Distribusi Frekuensi posttest Kelas Sampel

\begin{tabular}{|c|c|c|c|c|c|c|}
\hline \multirow{2}{*}{ No } & \multirow{2}{*}{$\begin{array}{c}\text { Skor } \\
\text { Posttest }\end{array}$} & \multirow{2}{*}{$\begin{array}{c}\text { Nilai } \\
\text { Posttest } \\
\end{array}$} & \multicolumn{2}{|c|}{ Kelas Eksperimen } & \multicolumn{2}{|c|}{ Kelas Kontrol } \\
\hline & & & Frekuensi & Jumlah Nilai & Frekuensi & Jumlah Nilai \\
\hline 1 & 15 & 60 & - & - & 2 & 120 \\
\hline 2 & 16 & 64 & - & - & 1 & 64 \\
\hline 3 & 17 & 68 & 3 & 204 & 4 & 272 \\
\hline 4 & 18 & 72 & 4 & 288 & 4 & 288 \\
\hline 5 & 19 & 76 & 2 & 152 & 7 & 532 \\
\hline 6 & 20 & 80 & 4 & 320 & 5 & 400 \\
\hline 7 & 21 & 84 & 5 & 420 & 3 & 252 \\
\hline 8 & 22 & 88 & 8 & 704 & 5 & 440 \\
\hline 9 & 23 & 92 & 5 & 460 & 3 & 276 \\
\hline 10 & 24 & 96 & 3 & 288 & 2 & 192 \\
\hline 11 & 25 & 100 & 2 & 200 & - & - \\
\hline \multicolumn{3}{|c|}{ Jumlah } & 36 & 3036 & 36 & 2836 \\
\hline \multicolumn{3}{|c|}{ Rata-Rata } & & 84,33 & & 78,78 \\
\hline
\end{tabular}

Tabel 4 memperlihatkan bahwa nilai posttest terendah pada kelas eksperimen adalah 68 yang diperoleh oleh 3 orang siswa dan nilai tertinggi adalah 100 diperoleh oleh 2 orang siswa. Nilai posttest terendah pada kelas kontrol adalah 60 yang diperoleh oleh 2 orang siswa dan nilai tertinggi adalah 96 diperoleh oleh 2 orang siswa. Nilai rata-rata posttest kelas eksperimen adalah 84,33 dan nilai rata-rata posttest kelas kontrol adalah 78,78.

Berdasarkan nilai KKM di SMAN 3 Pariaman yaitu 75, maka dapat diketahui persentase ketuntasan peserta didik pada posttest kelas eksperimen dan kelas kontrol adalah 80,55\% dan 69,44\%. Artinya, jumlah peserta didik yang mencapai KKM pada kelas eksperimen lebih banyak dibandingkan kelas kontrol. Berdasarkan nilai pretest dan posttest pada kelas sampel diatas, dapat dilihat kelas eksperimen mengalami signifikansi sebesar 49,22, sedangkan kelas kontrol 41,45, signifiknasinya dapat dilihat pada Tabel 5 . 
Tabel 5. Signifikansi nilai pretest dan posttest kelas sampel

\begin{tabular}{c|c|c|c} 
Kelas & Pretest & Posttest & Signifikansi \\
\hline Eksperimen & 35,11 & 84,33 & 49,22 \\
\hline Kontrol & 37.33 & 78,78 & 41,45
\end{tabular}

Data yang diperoleh dari pretest dan posttest selanjutnya diolah dan dianalisis guna untuk penarikan kesimpulan. Penarikan kesimpulan menggunakan uji kesamaan dua rata-rata atau uji-t dengan syarat data terdistribusi normal dan homogen. Sebelum melakukan uji-t terlebih dahulu dilakukan analisis data hasil belajar dengan uji N-Gain.

3.1.1. Uji N-Gain,Uji N-Gain bertujuan untuk mengetahui peningkatan pemahaman yang terjadi sebelum dan sesudah pembelajaran berdasarkan hasil pretest dan posttest pada kelas sampel. Hasil rata-rata uji N-Gain dapat dilihat pada Tabel 6.

Tabel 6. Hasil uji N-Gain Kelas Sampel

\begin{tabular}{c|c|c} 
Kelas & Rata-rata N-Gain & Kategori \\
\hline Eksperimen & 0,77 & Tinggi \\
\hline Kontrol & 0,67 & Sedang
\end{tabular}

Berdasarkan tabel 2, nilai rata-rata pretest hasil belajar pada kelas eksperimen adalah 35,11 dan kelas kontrol adalah 37.33. Selanjutnya, terjadi peningkatan nilai rata-rata pada posttest hasil belajar menjadi 84,33 dengan rata-rata N-gain sebesar 0,77 pada kelas eksperimen. Artinya, hasil belajar pada kelas eksperimen memiliki peningkatan dengan kategori tinggi. Sedangkan posttest hasil belajar pada kelas kontrol menjadi 78,78 dengan rata-rata $\mathrm{N}$-gain sebesar 0,67. Artinya, hasil belajar pada kelas kontrol memiliki peningkatan dengan kategori sedang.

3.1.2. Uji normalitas, Uji normalitas bertujuan untuk mengetahui apakah data berasal dari sampel yang terdistribusi normal atau tidak. Uji normalitas menggunakan uji Liliefors dengan hipotesis statistik yaitu:

$\mathrm{H}_{0}$ : data berdistribusi normal

$\mathrm{H}_{1}$ : data tidak berdistribusi normal

Kriteria pengambilan keputusasan adalah $\mathrm{H}_{0}$ diterima apabila $\mathrm{L}_{0}<\mathrm{L}_{\mathrm{t}}$ pada taraf nyata $\alpha=0,05$. Berdasarkan hasil pretest diperoleh uji normalitas kedua kelas sampel seperti terlihat pada Tabel 7.

Tabel 7. Hasil Uji Normalitas pretest Kelas Sampel

\begin{tabular}{c|c|c|c|c|c} 
Kelas & $\boldsymbol{\alpha}$ & $\mathbf{N}$ & $\mathbf{L}_{\mathbf{0}}$ & $\mathbf{L}_{\mathbf{t}}$ & Keterangan \\
\hline Eksperimen & \multirow{2}{*}{0,05} & 36 & 0,106 & 0,147 & Terdistribusi Normal \\
\cline { 3 - 6 } & \multirow{2}{*}{ Kontrol } & 36 & 0,093 & 0,147 & Terdistribusi Normal
\end{tabular}

Tabel 7 menunjukkan bahwa kedua kelas sampel mempunyai nilai $L_{o}<L_{t}$ pada taraf nyata $\alpha=$ 0,05 . Hal ini berarti data hasil pretest kedua kelas sampel terdistribusi normal. Selanjutnya untuk uji normalitas posttest terlihat pada Tabel 8.

Tabel 8. Hasil Uji Normalitas posttest Kelas Sampel

\begin{tabular}{c|c|c|c|c|c} 
Kelas & $\boldsymbol{\alpha}$ & $\mathbf{N}$ & $\mathbf{L}_{\mathbf{o}}$ & $\mathbf{L}_{\mathbf{t}}$ & Keterangan \\
\hline Eksperimen & \multirow{2}{*}{0,05} & 36 & 0,125 & 0,147 & Terdistribusi Normal \\
\cline { 3 - 6 } & \multirow{2}{*}{ Kontrol } & 36 & 0,139 & 0,147 & Terdistribusi Normal
\end{tabular}

Tabel 8 menunjukkan bahwa kedua kelas sampel mempunyai nilai $L_{o}<L_{t}$ pada taraf nyata $\alpha=0,05$. Hal ini berarti data hasil posttest kedua kelas sampel terdistribusi normal.

3.1.3. Uji homogenitas, Uji homogenitas bertujuan untuk mengetahui apakah sampel memiliki varians yang homogen atau tidak. Uji homogenitas dilakukan menggunakan uji $\mathrm{F}$ dengan hipotesis statistik yaitu: 
$\mathrm{H}_{0}$ : varians data homogen

$\mathrm{H}_{1}$ : varians data tidak homogen

Kriteria pengambilan keputusasan adalah terima $\mathrm{H}_{0}$ bila $\mathrm{F}_{\text {hitung }}<\mathrm{F}_{\text {tabel }}$ pada taraf nyata $\alpha=0,05$. Hasil uji homogenitas pretest kedua kelas sampel dapat dilihat pada Tabel 9.

Tabel 9. Hasil Uji Homogenitas pretest Kelas Sampel

\begin{tabular}{c|c|c|c|c|c} 
Kelas & $\mathbf{N}$ & $\mathbf{S}^{\mathbf{2}}$ & $\mathbf{F}_{\mathbf{h}}$ & $\mathbf{F}_{\mathbf{t}}$ & Keterangan \\
\hline Eksperimen & 36 & 83.30 & \multirow{2}{*}{1,174} & 1,84 & Homogen
\end{tabular}

Tabel 9 menunjukkan bahwa kedua kelas sampel mempunyai $\mathrm{F}_{\text {hitung }}<\mathrm{F}_{\text {tabel }}$ pada taraf nyata 0,05 . Hal ini berarti data hasil pretest kedua kelas sampel memiliki varians yang homogen. Selanjutnya untuk uji homogenitas posttest terlihat pada Tabel 10.

Tabel 10. Hasil Uji Homogenitas posttest Kelas Sampel

\begin{tabular}{c|c|c|c|c|c} 
Kelas & $\mathbf{N}$ & $\mathbf{S}^{\mathbf{2}}$ & $\mathbf{F}_{\mathbf{h}}$ & $\mathbf{F}_{\mathbf{t}}$ & Keterangan \\
\hline Eksperimen & 36 & 69.511 & \multirow{2}{*}{1,136} & 1,84 & Homogen
\end{tabular}

Tabel 10 menunjukkan bahwa kedua kelas sampel mempunyai $\mathrm{F}_{\text {hitung }}<\mathrm{F}_{\text {tabel }}$ pada taraf nyata $\alpha=0,05$. Hal ini berarti data hasil postest kedua kelas sampel memiliki varians yang homogen.

3.1.4. Uji hipotesis. Berdasarkan hasil analisis uji normalitas dan analisis uji homogenitas kelas eksperimen dan kelas kontrol menunjukkan bahwa data hasil belajar dari kedua kelas sampel terdistribusi normal dan mempunyai varians yang homogen. Oleh karena itu untuk menguji hipotesis dilakukan uji kesamaan dua rata-rata (uji-t) dengan hipotesis statistik yaitu:

$$
\begin{aligned}
& \mathrm{H}_{0}: \mu_{1}=\mu_{2} \\
& \mathrm{H}_{1}: \mu_{1}>\mu_{2} \\
& \text { Keterangan : } \\
& \mu_{1}=\text { rata-rata nilai kelas eksperimen } \\
& \mu_{2}=\text { rata-rata nilai kelas kontrol }
\end{aligned}
$$

Kriteria pengambilan keputusan adalah pada taraf nyata $\alpha=0,05$ terima $\mathrm{H}_{0}$ jika $\mathrm{t}_{\text {hitung }}<\mathrm{t}_{\text {tabel }}$ dimana $\mathrm{t}_{\text {tabel }}$ didapat dari daftar distribusi $\mathrm{t}$ dengan $\mathrm{dk}=\left(n_{1}+n_{2}-2\right)$ dan peluang $(1-\alpha)$. Berdasarkan hasil analisis data diperoleh uji hipotesis seperti yang dilihat pada Tabel 11.

Tabel 11. Hasil Uji Hipotesis Terhadap Hasil Belajar Kelas Sampel

\begin{tabular}{c|c|c|c|c|c} 
Kelas & $\mathbf{N}$ & $\bar{X}$ & $\mathbf{S}^{\mathbf{2}}$ & $\mathbf{t}_{\text {hitung }}$ & $\mathbf{t}_{\text {tabel }}$ \\
\hline Eksperimen & 36 & 84.33 & 68.511 & \multirow{2}{*}{2,607} & 1,67
\end{tabular}

Tabel 11 menunjukkan bahwa nilai $t_{\text {hitung }}>\mathrm{t}_{\text {tabel, }}$ maka $\mathrm{H}_{0}$ ditolak. Hal ini menunjukkan terdapat perbedaan hasil belajar pada kelas eksperimen dan kelas kontrol, dimana hasil belajar kelas eksperimen yang menggunakan media permainan ludo kimia berbasis CET lebih tinggi dibandingkan kelas kontrol yang tidak menggunakan media permainan ludo berbasis CET.

\subsection{Pembahasan}

Penelitian ini dilakukan untuk mengetahui tingkat efektivitas media permainan ludo kimia berbasis chemo-edutaiment (CET) pada materi Sistem Koloid terhadap hasil belajar siswa yang dilakukan di SMAN 3 Pariaman. Permainan ludo kimia berbasis CET ini berfungsi sebagai media pembelajaran untuk latihan dalam memantapkan konsep siswa pada materi Sistem Koloid. Untuk mengetahui sejauh mana pengetahuan awal yang dimiliki siswa terkait materi yang akan dipelajari, masing-masing kelas sampel yaitu kelas eksperimen dan kelas kontrol diberikan pretest terlebih dahulu. Data pretest juga dapat membantu guru memperkirakan mana materi yang harus diajarkan mendalam dan yang tidak, 
sehingga waktu pembelajaran akan lebih efektif.

Hasil belajar siswa kelas sampel sebelum diberi perlakuan pada Tabel 2 menunjukkan kemampuan awal siswa, dimana nilai rata-rata pretest kelas eksperimen adalah 35,11 dan kelas kontrol adalah 37,33. Nilai rata-rata pretest diatas menunjukkan bahwa kedua kelas sampel memiliki kemampuan awal yang hampir sama. Hal ini didukung hasil analisis uji-t pretest diperoleh nilai $\mathrm{t}_{\text {hitung }}(-1,0025)<\mathrm{t}_{\text {tabel }}(1,67)$ yang menyatakan tidak terdapat perbedaan hasil belajar antara kelas eksperimen dan kelas kontrol.

Setelah diberikan pretest, masing-masing kelas sampel dilakukanlah pembelajaran mengenai materi Sistem Koloid. Model pembelajaran, buku sumber, materi yang diajar, alokasi waktu, guru yang mengajar dan cara mengajar pada masing-masing kelas sampel adalah sama. Untuk pemantapan konsep siswa terkait materi yang telah dipelajari, maka pada akhir pembelajaran masing-masing kelas sampel diberi latihan soal-soal. Pemberian latihan dalam proses pembelajaran sangat penting dilakukan untuk memantapkan konsep siswa atas apa yang telah ia pelajari sebelumnya[12].

Pemberian latihan pada kelas kontrol menggunakan soal-soal yang ada pada buku paket sekolah, Sedangkan pada kelas eksperimen menggunakan media permainan ludo kimia berbasis CET. Latihan dilakukan pada pertemuan ke-III dengan alokasi waktu yang sama yaitu 80 menit. Setelah diberikan latihan, maka pada masing-masing kelas sampel diberikan posttest untuk menilai hasil belajar kognitif siswa.

Efektivitas penggunaan media permainan ludo kimia berbasis CET pada materi Sistem Koloid dilihat berdasarkan penguasaan materi oleh peserta didik yang diukur melalui persentase ketuntasan belajar dan skor N-gain. Berdasarkan perhitungan dari skor N-gain, diperoleh bahwa skor N-gain kelas eksperimen lebih tinggi secara signifikan dibandingkan kelas kontrol. Skor N-Gain untuk kelas eksperimen adalah 0,77 dengan kategori tinggi dan kelas kontrol 0,67 dengan kategori sedang. Artinya, peserta didik pada kelas eksperimen yang belajar menggunakan media permainan ludo berbasis CET untuk latihan memiliki hasil belajar yang lebih tinggi secara signifikan dibandingkan kelas kontrol yang belajar tanpa menggunakan media permainan ludo berbasis CET.

Perbedaan hasil belajar peserta didik pada kelas eksperimen dan kontrol juga dapat dilihat dari persentase ketuntasan belajar. Persentase ketuntasan belajar diperoleh dengan menghitung jumlah peserta didik yang mencapai batas Kriteria Ketuntasan Minimal (KKM) yang telah ditetapkan sekolah untuk kelas XI yaitu 75. Berdasarkan perolehan nilai posttest masing-masing peserta didik di kelas eskperimen, sebanyak 29 dari 36 peserta didik mencapai batas KKM, sehingga persentase ketuntasannya adalah $80,55 \%$ dengan rata-rata nilai yaitu 84,33 . Pada kelas kontrol hanya 25 dari 36 peserta didik yang mencapai KKM, sehingga persentase ketuntasannya hanya 69,44\% dengan rata-rata nilai 78,78.

Berdasarkan penjabaran diatas, dapat disimpulkan bahwa penggunaan media permainan ludo kimia berbasis CET dapat meningkatkan hasil belajar peserta didik. Penggunaan media pembelajaran dapat mempertinggi proses belajar dan dapat mempertinggi hasil belajar yang dicapai siswa[13]. karena pembelajaran dengan menggunakan media permainan merupakan sesuatu yang menyenangkan untuk dilakukan dan menghibur sehingga dapat meningkatkan partisipasi aktif dari siswa dalam proses pembelajaran[6].

Permainan ludo kimia berbasis CET ini dilakukan secara berkelompok yang sesuai dengan karakteristik siswa SMA. Salah satu kekhususan tingkah laku remaja adalah kesenangan berkeompok[3]. Penggunaan media permainan ludo kimia berbasis CET sebagai media pembelajaran membuat siswa merasa tertarik dan berpartisipasi aktif untuk mengerjakan latihan. Hal ini dapat dilihat dari antusiasme yang diberikan siswa berupa semangat yang tinggi dikarenakan ada unsur kompetisinya dan siswa termotivasi untuk menjadi pemenang. Permainan sebagai media pembelajaran akan membuat suasana belajar menjadi menyenangkan, sehingga siswa termotivasi dan dapat memahami pelajaran dengan baik selain itu unsur kompetisi yang membuat siswa ingin menang dalam permainan[14].

Permainan ini berisi banyak soal yang akan membuat siswa berulangkali menjawab pertanyaan untuk memenangkan permainan. Hal ini terlihat dimana setiap siswa memiliki empat buah bidak yang akan dijalankan untuk menuju finish. Dengan adanya empat buah bidak tersebut akan memberikan peluang yang besar kepada pemain untuk dapat mengulang menjawab soal-soal. Selain itu, ketika koordinator membacakan soal untuk pemain 1 maka pemain 2, 3, dan 4 juga ikut mendengarkan dan memperkirakan jawabannya. Begitu juga ketika koordinator membacakan soal untuk pemain 2 maka pemain 1, 3, dan 4 juga ikut mendengarkannya. Dengan adanya pengulangan-pengulangan tersebut, siswa yang kurang 
paham akan menjadi paham dan siswa yang telah paham menjadi lebih paham. Pengulangan, latihan dan penguatan merupakan suatu usaha dalam rangka memperkuat penguasaan hasil belajar[15].

Pembuktian adanya perbedaan hasil belajar siswa dengan menggunakan media permainan ludo berbasis CET sebagai media untuk latihan dengan hasil belajar siswa tanpa menggunakan media permainan ludo berbasis CET sebagai media untuk latihan dapat dibuktikan dengan uji statistik. Tabel 17 dan Tabel 19 menunjukkan hasil uji normalitas dan uji homogenitas kelas sampel, dimana hasil pengolahan data menunjukkan bahwa kedua kelas sampel terdistribusi normal dan memiliki varians yang homogen. Oleh karena itu, Pengujian hipotesis digunakan uji kesamaan dua rata-rata (uji-t) dengan hipotesis statistik yaitu:

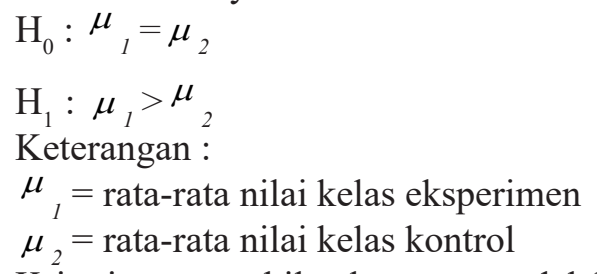

Kriteria pengambilan keputusan adalah pada taraf nyata $\alpha=0,05$ terima $\mathrm{H}_{0}$ jika $\mathrm{t}_{\text {hitung }}<\mathrm{t}_{\text {tabel }}$, dimana $\mathrm{t}_{\text {tabel }}$ didapat dari daftar distribusi $\mathrm{t}$ dengan $\mathrm{dk}=\left(n_{1}+n_{2}-2\right)$ dan peluang $(1-\alpha)$. Tabel 18 menunjukkan bahwa $\mathrm{t}_{\text {hitung }}(2,607)>\mathrm{t}_{\text {tabel }}(1,67)$, maka $\mathrm{H}_{0}$ ditolak. Adapun mengenai penolakan $\mathrm{H}_{0}$ dapat pula dilihat dari kurva daerah penerimaan dan penolakan $\mathrm{H}_{n}$ pada Gambar 1 .

\section{Uji Satu Pihak Kanan}

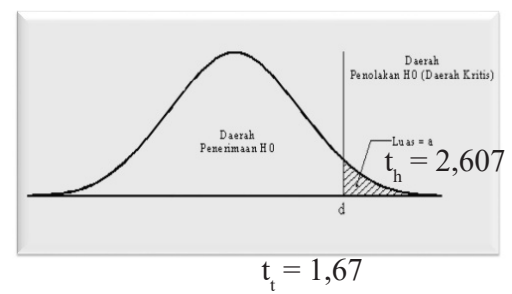

Gambar 1. Kurva Daerah Penerimaan dan Penolakan $\mathrm{H}_{0}[16]$

Gambar 1 memperlihatkan dari penelitian memberikan hasil $t_{\text {hitung }}=2,607$ yang jelas berada diluar daerah penerimaan $\mathrm{H}_{0}$. Jadi $\mathrm{H}_{0}$ ditolak. Hal ini menunjukkan bahwa terdapat perbedaan hasil belajar kelas eksperimen dan kelas kontrol dimana hasil belajar kelas eksperimen lebih tinggi dibandingkan hasil belajar kelas kontrol.

Secara keseluruhan penggunaan permainan ludo kimia berbasis CET sebagai media pembelajaran telah menerapkan prinsip belajar dari teori belajar kognitivisme. Menurut teori ini, pengetahuan datang dari tindakan, bergantung seberapa jauh siswa aktif dalam kegiatan belajar. Dalam proses belajar, yang menjadi titik dominan adalah terbentuknya struktur kognitif sebagai usaha pemecahan masalah.

\section{Simpulan}

Berdasarkan hasil penelitian, pengolahan data dan analisis data yang telah dilakukan tentang efektivitas penggunaan media permainan ludo kimia berbasis chemo-edutaiment (CET) pada materi Sistem Koloid terhadap hasil belajar siswa kelas XI SMAN 3 Pariaman dapat ditarik kesimpulan bahwasanya penggunaan media permainan ludo kimia berbasis chemo-edutaiment (CET) pada materi Sistem Koloid efektif dengan kategori tinggi dalam meningkatkan hasil belajar siswa kelas XI SMAN 3 Pariaman.

\section{Referensi}

[1] Kemendikbud. 2017. Lampiran Peraturan Menteri Pendidikan dan Kebudayaan Republik Indonesia Nomor 24 Tahun 2017 Tentang Silabus Mata Pelajaran Kimia Sekolah Menengah Atas/Madrasah Aliyah (SMA/MA). Jakarta: Kemendikbud.

[2] Smaldino, Sharon E, Deborah L. Lowther, \& James D. Russel. 2011. Instructional Technology \& Media for Learning. United States Of America.

[3] Mudjiran, dkk. 2007. Perkembangan Peserta Didik. Padang: UNP. 
[4] Muna, Nunung Faizul, Sri Hartati, dan Imam Setyawan. 2009. Hubungan Antara Kemandirian dengan Motif Berkompetisi pada Siswa Kelas VII Rintisan Sekolah Bertaraf Internasional, Jurnal Psikologi (Universitas Diponegoro): 1-20.

[5] UNESCO. 1988. Games Toys in The Teaching of Science and Technology. Paris: Division of Science Technical and Enviromental Educations.

[6] Sadiman, Arief S, dkk. 2012. Media Pendidikan Pengertian, Pengembangan, dan Pemanfaatannya. Jakarta: Raja Grafindo Persada.

[7] Yusuf, Y., dan Umi U. 2011. Sirkuit Pintar: Melejitkan Kemampuan Matematika \& Bahasa Inggris dengan Metoda Ular Tangga. Jakarta : Visim

[8] Nurfitrasari, Yan Sandi dan Woro Sumarni. 2015. Pengembangan Media Smile-Flash Berpendekatan Chemo-edutainment pada Materi Kelarutan dan Hasil Kali Kelarutan, Jurnal Inovasi Pendidikan Kimia, Vol.9(1).

[9] Febriyeni, Rahma dan Iswendi. 2019. "Pengembangan Ludo Kimia Berbasis Chemo-Edutaiment (CET) sebagai Media Pembelajaran pada Materi Sistem Koloid Kelas XI SMA/MA”, Skripsi. Padang: UNP.

[10] Sugiyono. 2013. Metode Penelitian Pendidikan (Pendekatan Kuantitatif, Kualitatif dan R\&D). Bandung: Alfabeta.

[11] Hake, Richard R. 1999. Analyzing Change/Gain Score. http://www.physic.indiana.edu/-sdi/ AnalyzingChange-Gain.pdf/. (di Akses tanggal 20 Februari 2019).

[12] Hamalik, O. 2008. Kurikulum dan Pembelajaran. Jakarta: Bumi Aksara.

[13] Sudjana. 2005. Metode Statistika. Bandung: Tarsito.

[14] Munandi, Yudhi. 2013. Media Pembelajaran: Sebuah Pendekatan Baru. Jakarta: Referensi.

[15] Sanjaya, W. 2013. Kurikulum dan Pembelajaran Teori dan Praktek Pengembangan KTSP. Jakarta: Kencana Prenada Media Group.

[16] Sudjana. 2005. Metode Statistika. Bandung: Tarsito. 